\title{
Un nitrato argentino: el Pericón Nacional (c.1906). Documentar para la construcción de una identidad nacional
}

Fecha de recepción: 30/08/2021. Fecha de aceptación: 12/10/2021

\begin{abstract}
Resumen
En este artículo analizaremos el contenido de uno de los pocos documentos de la primera mitad del siglo XX en soporte nitrato que se conservan en Argentina: el filme silente Pericón Nacional. Nos ubicamos en los comienzos de la historia del cine argentino y de las tecnologías cinematográficas con que se contaban a principios del siglo XX. Se trata de un caso de estudio que contempla una aproximación a la interpretación de las fuentes documentales primarias y secundarias, algo inusual para la investigación de este período, caracterizado por una enorme pérdida debido a la fragilidad que atraviesa el soporte, el contenido y la interpretación. Nos proponemos abordar este documento desde la óptica de la construcción de la memoria y la identidad nacional, considerando el contexto de crisis identitaria que atravesaba Argentina en esa época como consecuencia de la gran inmigración, mayoritariamente de composición italiana y española, y pensando el film como un instrumento de expansión y difusión de ideas políticas y culturales.
\end{abstract}

Palabras clave: preservación audiovisual, cine, teatro, cocoliche, patrimonio cinematográfico. Pericón Nacional

\section{An Argentine Nitrate; The National Pericon (c. 1906) Document for the Construction of a National Identity}

\begin{abstract}
In this article we will analyze the content of one of the few documents from the first half of the 2oth century in nitrate support that are preserved in Argentina: the silent film Pericón Nacional. We are located at the beginning of the history of Argentine cinema and of the available cinematographic technologies. This is a singular case study, since it allows for an interpretation of primary and secondary documentary sources, something unusual amongst the studies of this period, which is characterized by an enormous loss due to the fragility that affects the support, the content
\end{abstract}


and the interpretation. We aim to approach this document within the framework of memory construction and national identity, considering the context of identity crisis in Argentina at the time, as a consequence of the great immigration, mostly of Italian and Spanish origin, and thus thinking of the film as an instrument of expansion and diffusion of political and cultural ideas.

Keywords: audiovisual preservation, film, theater, Cocoliche, cinematographic heritage, The National Pericon, Pericón Nacional

\section{Introducción}

El Proyecto de investigación y digitalización del film Pericón Nacional (c. 1906), Un nitrato Argentino fue seleccionado en la convocatoria 2020 Activar Patrimonio del Ministerio de Cultura de la Nación. Se propuso continuar una intervención realizada en 2019, a cargo de la autora, que posibilitó la identificación de una pieza de nitrato $35 \mathrm{~mm}$., que pertenece al acervo del Instituto Nacional de Estudios de Teatro (INET). Teniendo en cuenta la temporalidad y fragilidad del material, se consideró relevante continuar la investigación para visibilizar un material histórico de más de cien años custodiado por INET, que da cuenta de la implicancia para la historia del teatro, el cine, la danza y la música folclórica argentina, para facilitar su difusión y acceso público a través de la digitalización en calidad $4 \mathrm{k}$. El avance del trabajo fue presentado en un ciclo de charlas organizado por el INET llamado "Mujeres investigando el archivo del INET" en la primera mitad de 2021 durante la pandemia Covid-19.

\section{La materialidad}

A través de la revisión y el diagnóstico de conservación del rollo del Pericón Nacional, completamos una ficha técnica diseñada para el acervo del INET donde todos los procesos se registraron y documentaron fotográficamente. Esos datos se trasladaron a una planilla en la que figuran otros materiales fílmicos y audiovisuales del acervo del INET. Documentar la metodología desplegada en los procesos de conservación de un documento audiovisual no es solo recuperar el soporte $35 \mathrm{~mm}$. como formato de conservación y exhibición, sino también es documentar estas prácticas para que trasciendan en la construcción de la salvaguarda del patrimonio cultural de una nación.

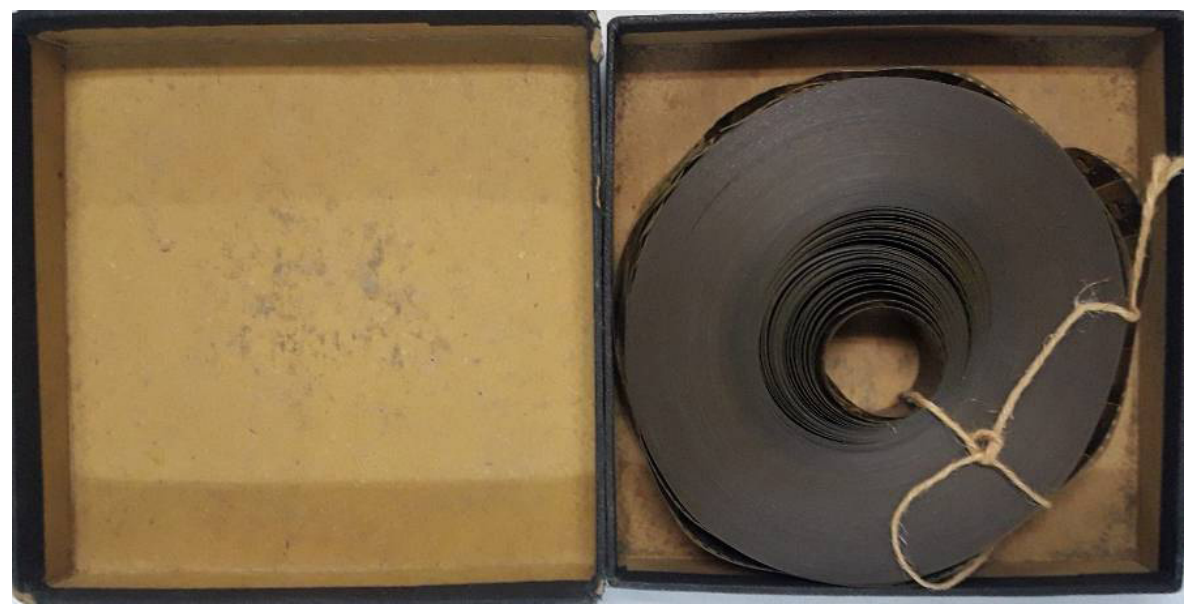

Caja original conteniendo el rollo de nitrato del film Pericón Nacional. Archivo del INET

Como resultado de la documentación podemos caracterizar al film del siguiente modo: es un único rollo en soporte nitrato de celulosa, formato $35 \mathrm{~mm}$., de fotografía blanco 
y negro; la emulsión es un positivo, ventanilla muda, en un estado de conservación regular; el encogimiento es de $0.5 \%$, con desprendimiento de emulsión en algunas zonas, con pérdida de perforaciones, deformaciones observadas mayormente en las espiras del comienzo del rollo, más expuestas al intercambio exterior donde el deterioro conocido como espejeo de plata es muy notorio. Es una copia silente, sin título en pantalla, sin marcas marginales, características que se presentaban en los primeros rollos del inicio del cine antes de normalizar las marcas comerciales en 1905. (Salomon, 2000: 2)

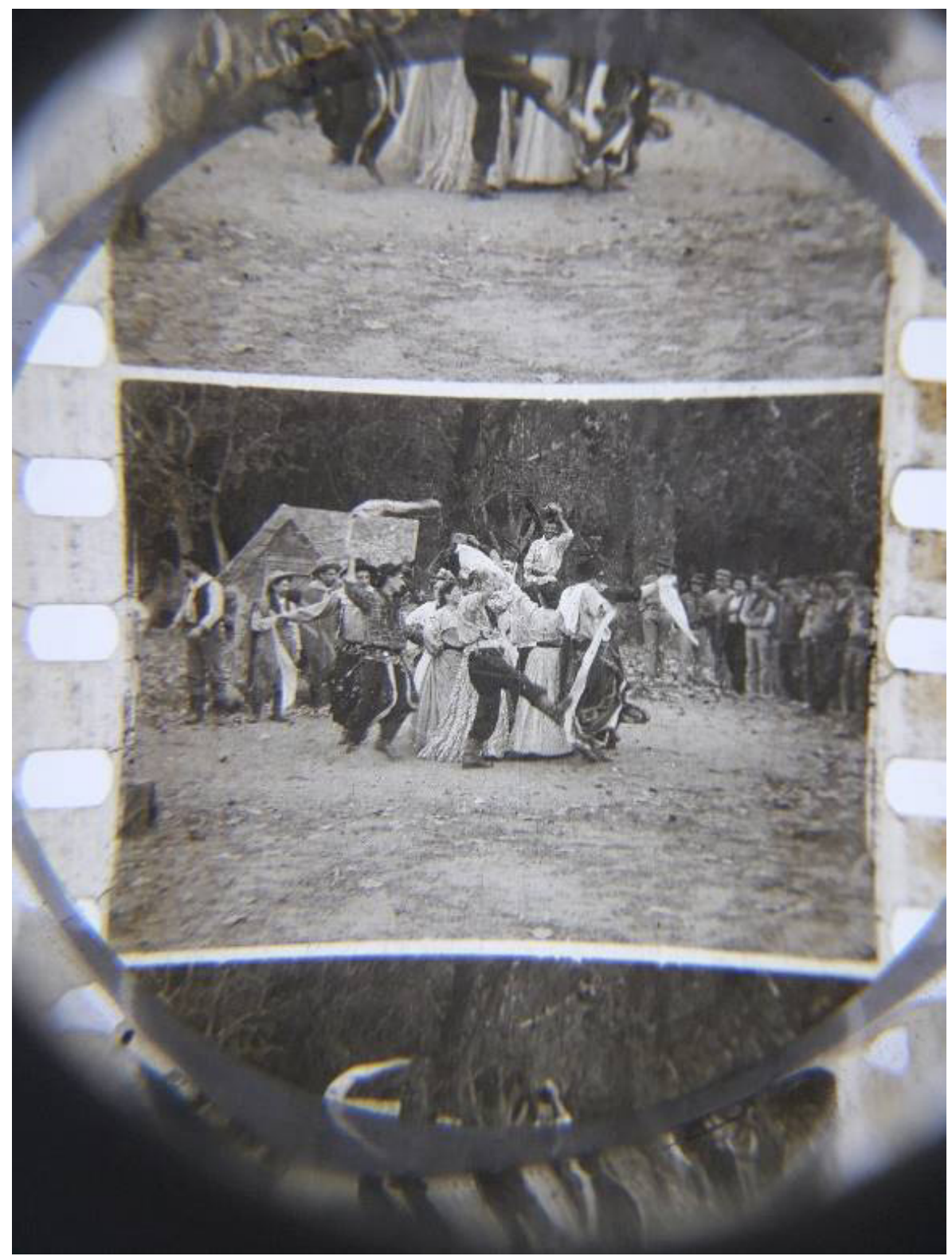

Fotograma del film Pericón Nacional. Archivo del INET

En los comienzos del cinematógrafo, las imágenes no contaban con sonido sincronizado en su soporte, pero estas imágenes a veces eran acompañadas por música en directo, según nos dice Altman (2007). El cine silente era filmado en rollos de 35 $\mathrm{mm}$. La mayoría de esos rollos se filmaron a velocidades más lentas que las películas con sonido-normalmente de 16 a 20 fotogramas por segundo. No obstante, algunas películas mudas fueron filmadas a menor velocidad de manera intencional. En los 
inicios del cine mudo, el plano que predomina era el plano general, en parte por el peso del cinematógrafo y, en parte, por las escenas que se representan al aire libre. Las famosas vistas del cinematógrafo eran planos exteriores generales, mayormente a cámara fija. Algo muy común eran las escenas populares filmadas en la calle, en jardines y los cortos documentales desde puntos altos o panorámicos. El film Pericón Nacional fue filmado y ambientado al aire libre, bajo una doble escenografía: por un lado, la escenografía teatral del rancho en una tela pintada colocado al fondo de la puesta y, por otro, la escenografía del espacio al aire libre; tal vez, el escenario del corto sean los bosques de Palermo de la Ciudad de Buenos Aires, lugar elegido en forma recurrente para presentaciones y espectáculos de la época, como también lo seria para vistas del cinematógrafo.

\section{Teatro y cinematógrafo}

Para comienzos del siglo XX, Buenos Aires era una ciudad con un gran desarrollo urbano y los espectáculos conjugaban lo local con lo foráneo llegado de Europa especialmente. El público que participaba de ellos demandaba un gran interés por las novedades, sin dejar de lado los tradicionales de azar, juegos de pelota, hasta los bailes al aire libre y, por supuesto, el circo y el teatro junto a la lírica reunían a sus propios públicos. Si bien el cine toma prestado temas de otras disciplinas, para el caso que nos ocupa, el teatro nos interesa espacialmente por ser la manifestación que guardara una relación cercana en cuanto a que buscaba beneficiarse de esta nueva forma visual, incorporando la tecnología del momento en las salas, surgiendo así una combinación de teatro y cinematógrafo, lo que posibilito el alcance a otros públicos más allá de las grandes urbes. En ese sentido, y siguiendo a Karina de Mauro,

desde finales del siglo XIX, el espectáculo en vivo fue la forma principal de entretenimiento, fundamentalmente en el creciente espacio urbano. Así, el circo criollo, el teatro de texto y los espectáculos de variedades se convirtieron en actividades comerciales de gran dinamismo. (2018;178),

En este clima cultural y de espectáculos, vale decir, años de constitución del campo teatral y de surgimiento y consolidación de un nuevo medio, el cinematógrafo, hace su arribo para luego ser incorporado al espectáculo. Como bien dice Cuarterolo (2019:237), estos tempranos films muestran esa dependencia del modelo teatral que se hace evidente en el mimetismo con que los filmes primitivos incorporan los mecanismos de expresión escénica desde la cámara ubicada en el punto de vista del espectador de la sala a la escena con los actores de pie y vueltos hacia el público, como así también a través de la utilización de fondos de cartón pintado, d maquillaje acentuado, los ademanes ampulosos y la puesta a cargo de las compañías teatrales.

La Revista Fotográfica Ilustrada del Rio de la Plata, que publicaba Enrique Lepage, para promocionar y comercializar su negocio, da cuenta de las famosas "vistas cinematográficas". En la Sección Cinematógrafos se describe un material fílmico con dos danzas, el Pericón y la Firmeza. Para ese momento, la temática del Pericón era un éxito del cinematógrafo, que ya contaba con una versión anterior difundida no solo en nuestro país, sino también en el extranjero. En la menciona sección, encontramos el relato fiel de cómo discurren las escenas que muestra el film del INET donde aparecen un núcleo de artistas nacionales reunidos para la danza, dirigidos por el primer actor Alfredo Merlo, sin precisar qué actores conforman el resto de la compañía. El punto clave y distintivo de este relato se hace evidente cuando se introduce el personaje teatral llamado "Cocoliche", una imagen estereotipada del inmigrante italiano, creado por la Compañía Podestá. 

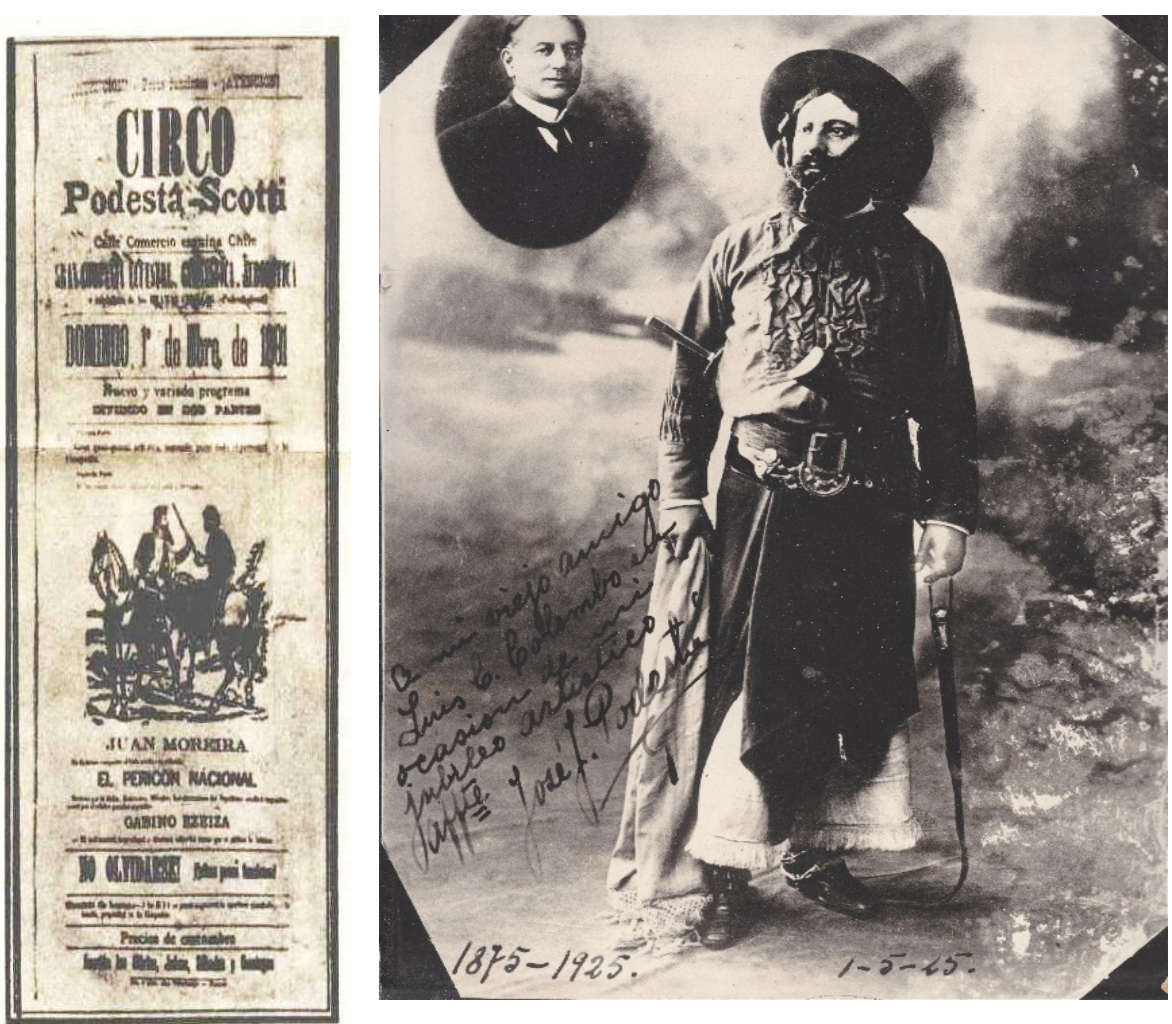

Programa de la representación de "Juan Moreira", el domingo $1^{9}$ de enero de 1891, cuando el circo estaba instalado en la esquins de Chile y Comercio.

Retrato de José Podestá. Fotografía y programa. Archivo del INET

En 1890, al final de la puesta en escena de Juan Moreira, se incorpora la danza El Pericón en reemplazo del gato, por ser “'“más apropiada y de mayor efecto para la fiesta campestre'"', según afirma Pepe Podestá (1930:57). Más aún, dado su éxito posteriormente será nombrada la danza nacional argentina. También sabemos cómo aparece mencionada en sus memorias (1930:62), de la introducción del personaje llamado Cocoliche, donde describe al personaje como una improvisación creada por Celestino Petray, quien imitó a un inmigrante calabrés cuyo nombre era Antonio Cocoliche:

un italiano acriollado que hacía gala de sus destrezas criollas mientras exhibía su ineficacia absoluta en el manejo de las mismas, y que cruzaba en su discurso el italiano y la lengua gauchesca, idiolecto que se fijó como convención teatral y que recibió su nombre.

El impacto social de la inmigración, según Gladys Onega (1982), se vio reflejado en el teatro argentino a través de los diferentes géneros como el drama rural, el drama gaucho y el sainete, que representaban a la población cosmopolita de las ciudades en forma de estereotipos graciosos o de trabajadores explotados donde la figura del inmigrante aparece a través de lugares comunes que caracterizaban a los extranjeros.

\section{El Cocoliche}

El personaje del Cocoliche, desde su aparición en el corto y las imágenes que se suceden, adquiere un protagonismo llamativo, una vez que el grupo se concentra en el centro de la puesta despojada al exterior, con el rancho en un telón pintado. Previo 
al comienzo de la danza mediante un corte, la cámara se acerca, posicionándolo como figura central, rodeado por el resto de los actores, quienes acompañan con risas y gestos las ocurrencias de comicidad que genera la interpretación caricaturizada , estimulando así las risas del público. Cabe destacar que el actor que interpreta al Cocoliche aún no está identificado, luego se le dedica una toma más cercana, de cuerpo entero para repetir la escena anterior donde juega con el mate. El actor mira en un determinado momento a la cámara tal vez esperando indicaciones del cinematografista. Todo esto sucede en un lapso de quince segundos para luego volver en la toma siguiente de un plano general. Este pasaje con la intervención protagónica del cocoliche bien podría considerarse un rasgo fundante propio de las posibilidades del cinematógrafo, donde a través de la repetición accedemos a una lógica propia de sentido, usada en el teatro popular, pero puesta a disposición de la cámara, desde un punto de vista donde se muestra el detalle y la improvisación y se transparenta a las claras que el trabajo realizado por el grupo de actores y su director fue ensayado muy seriamente para toda la duración del registro fílmico. No podemos dejar de mencionar la introducción de un elemento sorpresa, de mucha delicadeza cuando aparece un niño de temprana edad vestido de gaucho en un costado del encuadre para situarse luego en el centro de este; la actitud seria y la mirada fija a la cámara lo muestran concentrado para realizar su cometido, saludar al público quitándose su sombrero, mientras, de fondo, la compañía continúa danzando. El baile del Pericón es dirigido por el primer actor Alfredo Merlo, según la fuente secundaria, quien pertenecía a la compañía de la familia Rafetto en ese periodo, según documentos y fotografías conservados en el acervo del INET.

De modo que, citando la genealogía del teatro rioplatense, esto nos remite a la creación del drama criollo Juan Moreira, obra cumbre de don José Podestá, que Laura Mogliani describe como el hito originario a partir del cual cobró existencia el teatro nacional (2015:313), surgiendo a lo largo de los años en la cultura de local una gran identificación que lo convirtió en un éxito que lo afianzaría como género teatral. De manera que, así como el llamado "género chico" inspiró el nacimiento del teatro nacional, y, por su parte, el "drama gauchesco" que nació en el picadero del circo, este se convirtió en el espectáculo popular identitario.

Posteriormente, la Compañía Hermanos Podestá asentados en el Teatro Apolo desde el 6 de abril de 1901, filmarían a un año de inaugurado el teatro, en 1902, una de las versiones del Pericón Nacional, que luego sería exhibida en una gira por las cortes europeas con una excelente recepción. De ahí que, trasladándose la noticia a las costas porteñas, el impacto en las costumbres locales hizo que la danza fuera bien recibida en los salones de la elite de Buenos Aires (Caneto, 1996:66).

De este modo, en el inicio de esta investigación, una de las hipótesis que surgió fue que estábamos frente al rollo fílmico en el que había participado la compañía Podestá, ya que el INET custodia diferentes materiales relacionados esta familia fundacional del teatro argentino. También podemos mencionar que, en cuanto al actor Alfredo Merlo, el INET posee fotografías en diferentes momentos de su carrera, así como de la compañía Rafetto de la cual tomo parte por eso años. 

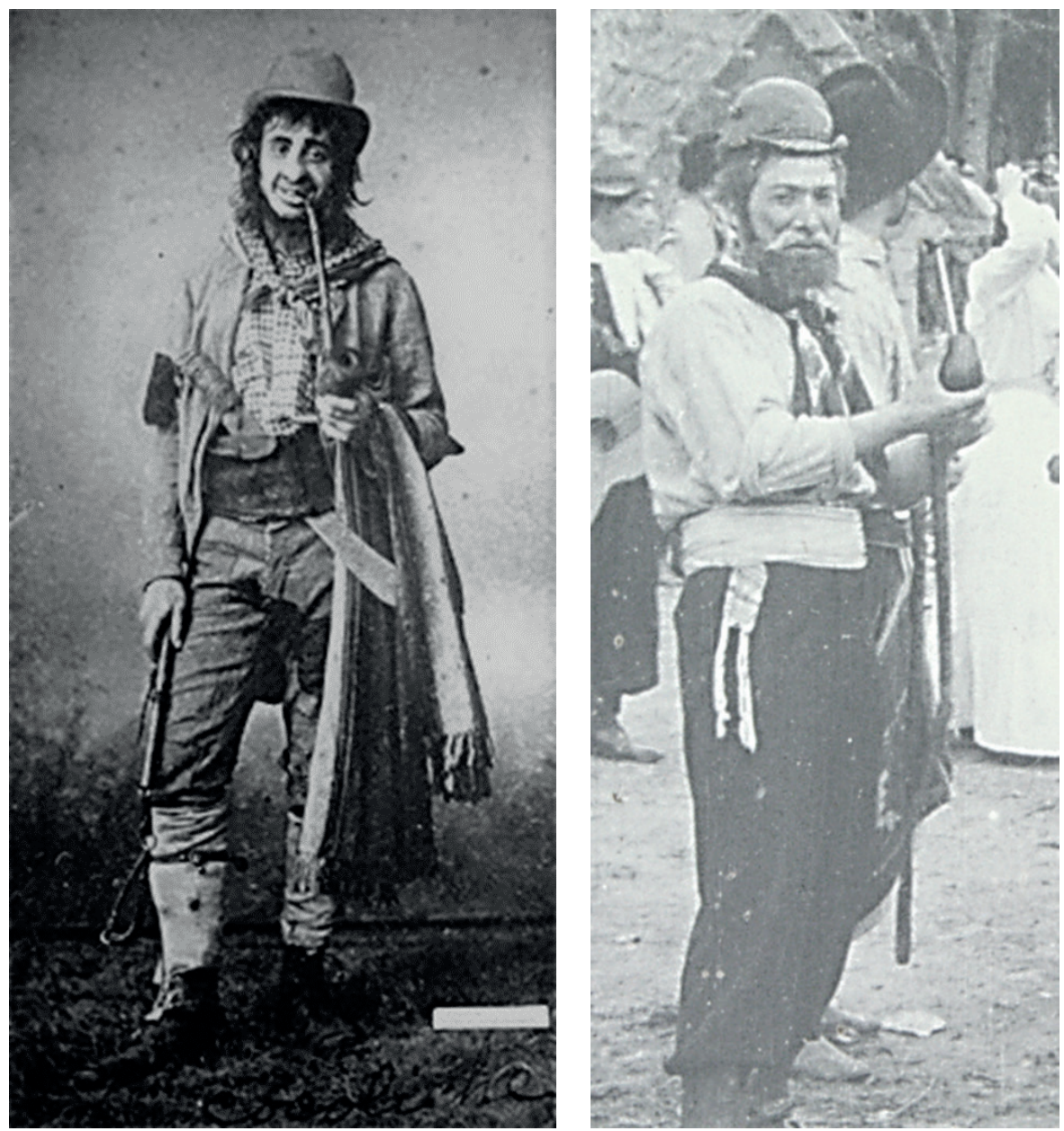

Caracterizaciones del Cocoliche. Fotografía y fotograma del film. Archivo documental del INET

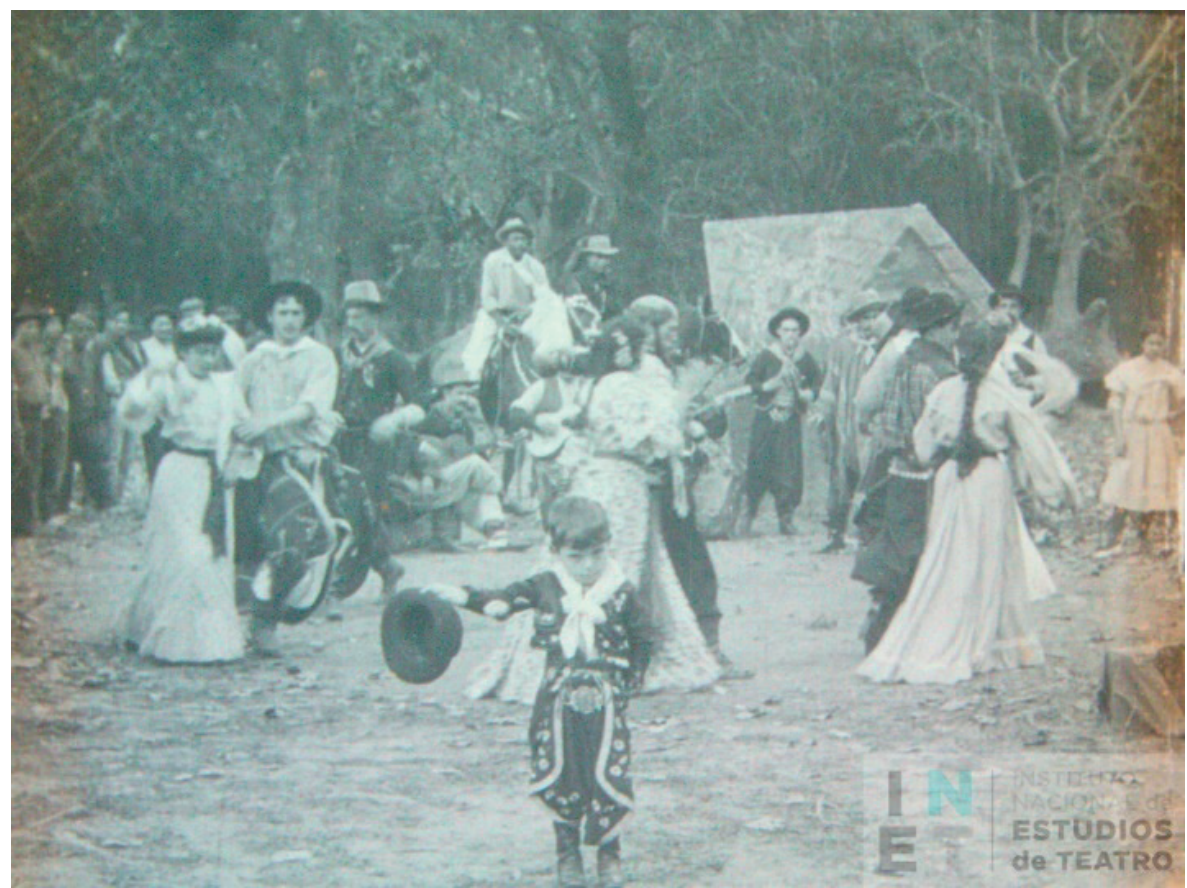

Fotograma del film Pericón Nacional. Archivo del INET 


\section{La Exposición Universal}

La Revista también menciona la solicitud por parte del representante italiano en nuestro país para la Exposición Universal de Milán de , de la cual Argentina participo juntos a otros países de la región y su presentación se ubicó en el pabellón de Sudamérica. El espectáculo de la innovación industrial en las exposiciones universales tenía como propósito mostrar al gran público internacional los avances de la ciencia y la industria surgidos en el marco de la revolución industrial. Podemos ilustrar que las exposiciones universales eran eventos a los que acudían todo tipo de público y consumidores, según Della Coletta (2006: 53), a finales del siglo XIX y principios del XX. Italia acogió numerosas exposiciones nacionales e internacionales que exponían las nociones de identidad nacional, expansión imperial, progreso tecnológico y crecimiento capitalista. La Exposición internacional Milán o Exposición Internacional del Sempione, que se efectuó del 28 de abril al 11 de noviembre de1906, fue construida en el área del actual Parque del Sempione, partiendo del túnel de Sempione (del cual la exposición toma el nombre) como inspiración según enumera Misiano $(2014,3)$ ya que fue la primera línea ferroviaria directa Milán-París y se inauguró en febrero de 1905. Así la Muestra Internacional de Transporte, el abastecimiento y las Bellas Artes, en la que las naciones participantes fueron cuarenta, los expositores treinta y cinco mil, y los visitantes se estimaron en más de cinco millones, una cifra récord para la época. La imagen oficial de la exposición fue seleccionada a través de un concurso y representa una alegoría del progreso técnico científico. En el cartel se ve al dios del comercio Mercurio y la Ciencia, iluminados por el resplandor rojizo del fuego de la locomotora, que salen del túnel y miran hacia la ciudad de Milán, donde se reconoce la silueta del Duomo.

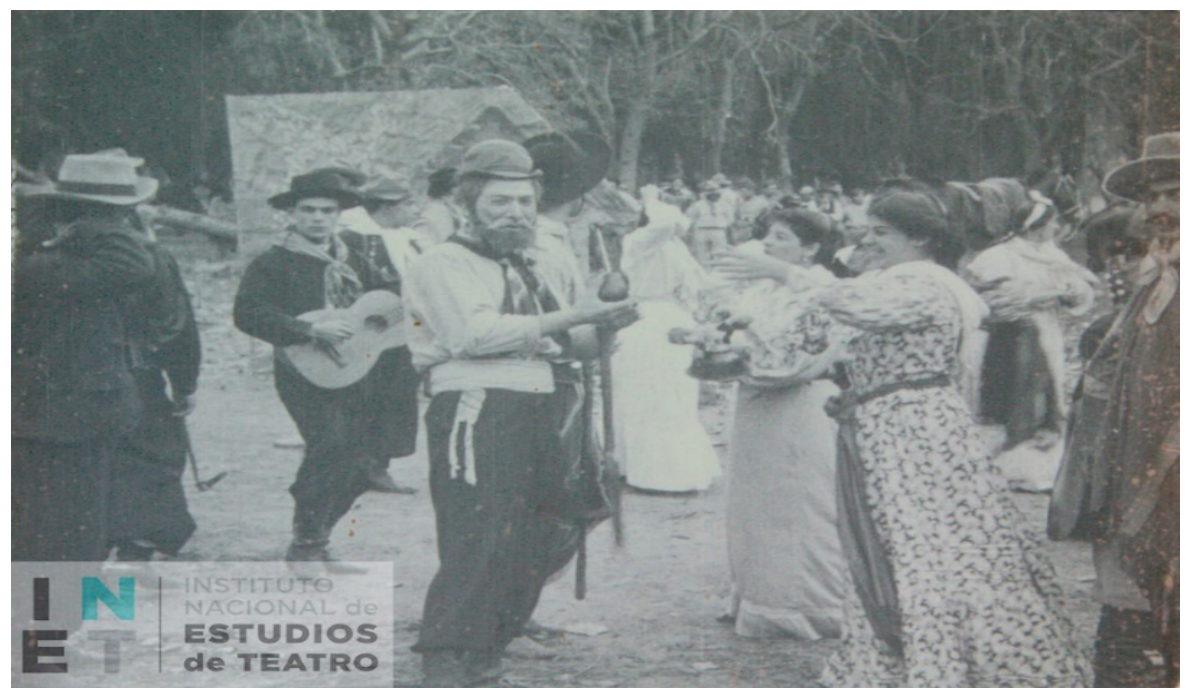

Fotograma del film Pericón Nacional. Archivo del INET

En cuanto a la puesta que incluye a un representante italiano dentro del repertorio de una danza popular como el Pericón Nacional, es posible atribuir la intención destinada a promover la cultura local durante la exposición, donde el film sería exhibido en los numerosos cinematógrafos dispuestos en diferentes ubicaciones del predio. Además, es factible que el documental haya sido puesto en competencia, como tal es el caso del envío a la exposición Internacional de París en 1902 (Maranghello,2005;16), donde la Casa Lepage terminaría obteniendo una medalla de oro. Se percibe en este pedido de un funcionario italiano, la necesidad de mostrar una danza nacional, interpretada por actores nacionales como un instrumento de expansión y difusión de ideas políticas y culturales, siendo Argentina atravesaba por los efectos de la inmigración italiana y 
española en su composición mayoritaria, situación que plasmaría como consecuencia una crisis identitaria. La propuesta de las clases sociales asociadas al poder, de reaccionar frente a estos cambios sociales, vislumbro en el cine con su alcance masivo un medio ideal para la integración nacional. El caso que nos ocupa es un claro ejemplo de fusión entre lo criollo y lo extranjero, de los diferentes lenguajes y costumbres que se asocian para el surgimiento de un sentimiento patriótico compartido donde llamativamente no aparecen miembros de la élite local, o de una ceremonia propiciada o dirigida a ellos, más bien es la representación de un espacio de lo que sucedería posteriormente en el cine de ficción cercano al centenario de la república, donde sí parece la temática del campo, los gauchos y sus destrezas, que ponen en evidencia el objetivo mayor de esta tecnología al servicio de los imaginarios sociales colectivos.

Retomado la serie de datos enunciados de las fuentes secundarias y primarias podemos argumentar que, si bien la intención de documentar es inaugural con relación a las repercusiones del cinematógrafo, la noción de recrear un material como la danza del Pericón, que había sido exitoso traspasando las fronteras del propio país, adquiere relevancia al crear un material que diera cuenta de las prácticas representativas de la cultural local, ya no sólo desde una danza nacional, sino también desde la integración del inmigrante al contexto nacional. Se trata, en efecto, de un inmigrante que procede del ámbito rural, cercano y conocido de la familia Podestá, que deviene en personaje de la ficción de Juan Moreira y , en poco tiempo, alcanza la legitimación del público local a través del humor en la mezcla hibrida de su lenguaje y la gracia torpe de sus gestos impropios de la urbe. Estas prácticas se trasladan posteriormente al cine. En esta línea argumentativa, nos parece apropiada la tesis que propone Cuarterolo (2013:29) en relación a estos nuevos cambios sociales, culturales y tecnológicos que transformaron la visión del espectador y su experiencia con la realidad. En consecuencia, el cine bien pudo ser una poderosa herramienta discursiva que buscó transmitir esas nuevas configuraciones y dar cuenta de estas representaciones de la realidad impactando en la conformación de la identidad nacional. Se comienza así a esbozar temáticas nacionalistas que surgen en esta etapa con la demanda de creaciones cinematográficas con influencia de lo extranjero.

\section{Conclusion}

El documento fílmico da cuenta de un valioso aporte a la historia de los comienzos del cine argentino y, a la vez, habilita nuevas relaciones con estudios de otras disciplinas como la danza, el teatro y la música. La idea de confluir en un espectáculo de danza a el personaje inmigrante salido del teatro, un niño vestido de gaucho, músicos y destrezas de jinetes nos hace pensar en los ya conocidos espectáculos de variedades y el creciente papel que comienzan a tener en la transición de siglo. Estos espectáculos populares pudieron adaptarse a una sociedad con ansias de modernización, que abandonaba poco a poco su etapa de aldea. Entonces, encontramos una evidencia doble: por un lado, en participar en las consonancias progresistas de la época a través del temática, con una danza popular que incluye un personaje extranjero habitante del territorio nacional y, por el otro, la técnica que media esa transmisión, el cinematógrafo, encaminado a afianzarse como sistema de registro documental. En efecto, el teatro porteño proveniente de un origen popular como el circo, conformado por artistas criollos e inmigrantes, comparte su condición social con el público, incorporando formas y contenidos valorados por el mismo que repercuten en su condición prospera de espectáculo colectivo.

Por último, los datos que pudimos relevar a partir de la revisión y el diagnóstico del material fílmico nos permitieron dar el marco al trabajo de restauración física, digitalización y contrastarlas con la investigación de las fuentes documentales secundarias. 
Una vez digitalizado pudimos analizar el material a partir de su visionado, cabe insistir que es inusual en acceso a la fuente primaria para los investigadores de la historia cinematográfica argentina. Un film que había permanecido sin poder conocerse por décadas sale a luz gracias al desarrollo de nuevas tecnologías y la laboriosidad de especialistas en la conservación audiovisual que posibilitan el acceso y la preservación, en cuanto nos ayuda a entender las prácticas de producción y realización cinematográfica de la época al tener en nuestras manos un nitrato silente $35 \mathrm{~mm}$. de ciento quince años. A partir del acceso al material en formato digital y disponer de las imágenes en su formato de fotograma se abren aspectos que inscriben al material e inscribirlo en la historia de diversas disciplinas como el cine, el circo, el teatro, la danza y la música. Cruces que ya vienen dados en la conformación de este fiilm, que ha prevalecido por más de cien años y adquiere así un valor documental histórico. 


\section{Dibliografia}

» Altman, R. (2004). Vaudeville. En Altman, R, In Silent Film Sound, New York: Columbia University, pp. 95-115.

" Caneto, G. et al. (1996). Historia de los primeros años del cine en la Argentina (1895-1910). Buenos Aires: Fundación Cinemateca Argentina.

"Cuaterolo, A. (2019). "El cine histórico argentino durante el período silente: Dos modelos estéticos e ideológicos en pugna". Traducción al español de la autora, Vivomatografias. Revista de estudios sobre precine y cine silente en Latinoamérica, n. 5 (6), 233-276. Disponible en: http://www.vivomatografias.com/ index.php/vmfs/article/view/258

"Cuarterolo, A. (2013). De la foto al fotograma. Relaciones entre cine y fotografía en la Argentina (1840-1933) Montevideo, CdF Ediciones.

»Del Amo García, Alfonso. (2006). Clasificar para preservar. México: Cineteca Nacional de México.

" Mauro, K. (2018). “Identidades y apelaciones antagónicas de los trabajadores del espectáculo (1902-1955)” (pp.176-231). telondefondo. Revista de Teoría y Crítica Teatral, N²7. Disponible en: https://doi.org/10.34096/tdf.n27.5100

» Maranghello, C. (2005). Breve historia del cine argentino. Buenos Aire: Ed. Laertes.

" Misiano, F, (2021). L'Esposizione del Sempione 1906. Milano in vetrina, Diacronie $\mathrm{N}^{\circ} 18,2 \mid 2014$, documento 9, Publicado el 01 junio 2014, consultado el 30/05/2021. Disponible en: https://doi.org/10.4000/diacronie.1450

»Mogliani L. (2015). Nativismo y Costumbrismo en el teatro argentino. - 1a ed. Buenos Aires. E-Book. 204

"Onega, Gladys (1982). La inmigración en la literatura argentina (1880 - 1910). Buenos Aires: Centro Editor de América Latina.

"Pellettieri, O. (Dir.) (2009). Diccionario biográfico estético del actor en Buenos Aires. Vol. I. Garlena.

》Podestá J. (1930). Medio siglo de farándula: memorias de José J. Podestá, Buenos Aires, Río de la Plata, p. 57-62.

"Salomom, M. (2000). Sculteurs de lumières. Les directeurs de la photographie. París: Bibliothèque du Film (BiFi). p. 2

\section{Otras fuentes}

》 Revista Fotográfica llustrada del Rio de la Plata №154 de junio,1906-

»Reporte realizado por Laura Gómez-Conservadora para el INET 